\title{
Chemical Cleaning of Ultrafiltration Membrane Fouled by Humic Substances: Comparison between Hydrogen Peroxide and Sodium Hypochlorite
}

\author{
Kai Li ${ }^{1,2, *(1)}$, Shu Li ${ }^{1,2}$, Tinglin Huang ${ }^{1,2, *}$, Chongzhe Dong ${ }^{1,2}$, Jiawei $\mathrm{Li}^{1,2}$, Bo Zhao ${ }^{1,2}$ and \\ Shujia Zhang ${ }^{1,2}$ \\ 1 Key Laboratory of Northwest Water Resource, Environment and Ecology, MOE, Xi'an University of \\ Architecture and Technology, Xi'an 710055, China \\ 2 Shaanxi Key Laboratory of Environmental Engineering, Xi'an University of Architecture and Technology, \\ Xi'an 710055, China \\ * Correspondence: likai@xauat.edu.cn (K.L.); huangtinglin@xauat.edu.cn (T.H.); \\ Tel.: +86-029-8220-7886 (K.L.); +86-029-8220-1038 (T.H.)
}

Received: 15 June 2019; Accepted: 17 July 2019; Published: 18 July 2019

\begin{abstract}
Chemical cleaning is indispensable for the sustainable operation of ultrafiltration (UF) system in water and wastewater treatment. Sodium hypochlorite $(\mathrm{NaClO})$ is an established cleaning agent for membranes subject to organic and microbial fouling, but concerns have been raised about the generation of toxic halogenated by-products during $\mathrm{NaClO}$ cleaning. Hydrogen peroxide $\left(\mathrm{H}_{2} \mathrm{O}_{2}\right)$ is a potential "green" cleaning agent that can avoid the formation of halogenated by-products. In this work, cleaning efficacy of $\mathrm{H}_{2} \mathrm{O}_{2}$ and $\mathrm{NaClO}$ for UF membrane fouled by humic substances (HS) was evaluated under a wide $\mathrm{pH}$ range, and change of $\mathrm{HS}^{\prime}$ s properties due to reaction with cleaning agents was examined. The cleaning efficacy of $\mathrm{H}_{2} \mathrm{O}_{2}$ was lower than that of $\mathrm{NaClO}$ at $\mathrm{pH} 3-9$, but it increased to a level (91.4\%) comparable with that of $\mathrm{NaClO}$ at $\mathrm{pH} 11$. The extents of changes in properties and fouling potential of $\mathrm{HS}$ due to reacting with cleaning agents were consistent with their cleaning efficacy. $\mathrm{H}_{2} \mathrm{O}_{2}$ treatment at $\mathrm{pH} 11$ significantly increased negative charge of $\mathrm{HS}$ molecules, decomposed high-MW molecules, and reduced its fouling potential. Therefore, considering treatment/disposal of cleaning waste and cleaning efficacy, $\mathrm{H}_{2} \mathrm{O}_{2}$ cleaning under strong alkaline condition can be a good choice for HS-fouled membrane.
\end{abstract}

Keywords: ultrafiltration (UF) membrane; humic substances (HS) fouling; chemical cleaning; hydrogen peroxide $\left(\mathrm{H}_{2} \mathrm{O}_{2}\right)$; sodium hypochlorite $(\mathrm{NaClO})$

\section{Introduction}

In the past few decades, the application of ultrafiltration (UF) in water industry has increased rapidly because of its small footprint and efficient and reliable removal towards particles and pathogens $[1,2]$. Nevertheless, membrane fouling, i.e., the decrease of membrane permeability due to accumulation of organic/inorganic/biological substances on/within membrane, is one of the major bottlenecks of UF technology [3,4]. Membrane fouling results in the decline of membrane flux for constant pressure system or the increase of trans-membrane pressure (TMP) for constant flux system, which would impair system productivity and increase operating costs [5]. Although many efforts, such as pretreatment of feed water [6,7], membrane material modification [8,9], and operation optimization $[10,11]$, have been made to mitigate membrane fouling, build-up of physically irreversible fouling during long-term operation is still inevitable [12]. Therefore, chemical cleaning has to be conducted periodically to remove foulants deposited on/with membrane and restore membrane permeability $[13,14]$. 
Many chemical reagents have been used as cleaning agents for UF membrane, including acids, alkalis, oxidants, surfactants, and complexing agents [15]. Among them, sodium hypochlorite ( $\mathrm{NaClO})$ is one of the most commonly used oxidative cleaning agents because of its cost-effectiveness and ease to use. For organic fouling, $\mathrm{NaClO}$ cleaning can alter functional groups, molecular size, surface charge, and hydrophilicity of organics, resulting in the decrease of foulants-membrane interactions and dislodgement of organic foulants $[12,16,17]$. However, the reactions between $\mathrm{NaClO}$ and organic foulants/membrane material would inevitably generate toxic halogenated by-products [18-21]. It is estimated that the total organic halogenated material discharged by on-line $\mathrm{NaClO}$ cleaning of membrane bioreactors (MBRs) in China would reach $648.45 \mathrm{~kg} /$ year according to the current MBR processing capacity and cleaning conditions [22]. Therefore, $\mathrm{NaClO}$ cleaning waste should be carefully treated and disposed, leading to the increase of chemicals consumption and operation costs.

Compared with $\mathrm{NaClO}$, hydrogen peroxide $\left(\mathrm{H}_{2} \mathrm{O}_{2}\right)$ is regarded as a green oxidant because its reduction product is water $\left(\mathrm{H}_{2} \mathrm{O}\right)$, and the formation of halogenated by-products can be avoided. Although reactivity of $\mathrm{H}_{2} \mathrm{O}_{2}$ is restricted by a high activation energy barrier, it is still a potential oxidative cleaning agent and has been investigated in several studies. For polysulfone membrane fouled by fermentation broth, flux was restored to $80 \%$ of the initial flux of new membrane after washing with $3 \mathrm{~g} / \mathrm{L}$ of $\mathrm{H}_{2} \mathrm{O}_{2}(\mathrm{pH}=3.6)$, which was significantly higher than $\mathrm{HCl}$ and $\mathrm{NaOH}$ [23]. Strugholtz et al. [24] examined cleaning efficacy of $\mathrm{H}_{2} \mathrm{O}_{2}$ for membrane fouled by flocculated reservoir water, and no flux recovery was obtained with no $\mathrm{pH}$ adjustment, but the cleaning efficacy was significantly improved after adjusting solution $\mathrm{pH}$ to 12 . Wang et al. [25] reported that $\mathrm{H}_{2} \mathrm{O}_{2}$ cleaning obtained the highest flux recovery for fouled forward osmosis membrane in anaerobic osmotic MBR, whereas chelate, surfactant, acids, and alkali cannot effectively remove foulants on the membrane. However, Kuzmenko et al. [26] found that $\mathrm{H}_{2} \mathrm{O}_{2}$ cleaning ( $\mathrm{pH}$ and concentration not given) even reduced membrane flux further (the specific flux decreased from 0.60 to 0.52 ), whereas $\mathrm{NaClO}$ cleaning achieved significant flux recovery. For polyethersulfone (PES) membrane fouled by paper-making wastewater, no flux recovery was achieved after cleaning with $2 \% \mathrm{H}_{2} \mathrm{O}_{2}$ (without $\mathrm{pH}$ adjustment) [27]. In general, compared with $\mathrm{NaClO}$ cleaning, much less attention has been paid to $\mathrm{H}_{2} \mathrm{O}_{2}$ cleaning, and the cleaning efficacy reported in literature seems contradictory. Meanwhile, cleaning mechanisms of $\mathrm{H}_{2} \mathrm{O}_{2}$ and its interactions with organic membrane foulants are still unclear.

$\mathrm{H}_{2} \mathrm{O}_{2}$ is a very weak acid with a pKa of $11.62\left(\mathrm{~T}=25^{\circ} \mathrm{C}\right)$, and only under alkaline conditions it would be dissociated to form $\mathrm{HO}_{2}{ }^{-}$, which is believed to be an active species for bleaching and degradation of some dyes. Moreover, several studies reported that $\mathrm{H}_{2} \mathrm{O}_{2}$ can be activated by alkali to generate reactive oxygen species, such as superoxide radical $\left(\mathrm{O}_{2}{ }^{-}\right)$and singlet oxygen $\left({ }^{1} \mathrm{O}_{2}\right)[28]$. As a result, it is expected that the cleaning efficacy of $\mathrm{H}_{2} \mathrm{O}_{2}$ would be strongly affected by solution $\mathrm{pH}$, but few studies have comprehensively examined this issue. In this work, cleaning efficacy of $\mathrm{H}_{2} \mathrm{O}_{2}$ for UF membrane fouled by humic substance (HS) at a wide $\mathrm{pH}$ range (3-11) was investigated, and $\mathrm{NaClO}$ cleaning was conducted as the reference. To elucidate cleaning mechanisms, fouling potential and properties of HS before and after reaction with cleaning agents at optimum $\mathrm{pH}$ were analyzed.

\section{Materials and Methods}

\subsection{Membrane and Filtration Set-Up}

Flat-sheet PES membranes (UP150, Microdyn-Nadir, Wiesbaden, Germany) with a molecular weight cutoff (MWCO) of $150 \mathrm{kDa}$ and an effective surface area of $45 \mathrm{~cm}^{2}$ were used for evaluation of both cleaning efficacy and fouling potential of HS. According to the manufacturer, the membrane material is blended with hydrophilic additives, and pure water contact angle of the membrane is $45 \pm$ $4{ }^{\circ} \mathrm{C}$. Meanwhile, the membrane surface is negatively charged with a zeta potential of $-17 \pm 3 \mathrm{mV}$ at $\mathrm{pH}$ 7. To ensure thorough removal of preservative agents, new membranes were soaked in ultrapure water (18.2 M $\Omega \mathrm{cm}$, ELGA LabWater's, High Wycombe, UK) for at least $24 \mathrm{~h}$, and $150 \mathrm{~mL}$ ultrapure 
water was filtered before use. The initial pure water flux of the membranes used in this study was in the range of $410 \pm 10 \mathrm{~L} /\left(\mathrm{m}^{2} \cdot \mathrm{h}\right)$ at a TMP of $100 \mathrm{kPa}$.

Filtration experiments were carried out in a filtration cell (Amicon 8400, Millipore, Burlington, MA, USA) in dead-end mode at room temperature $\left(25 \pm 1^{\circ} \mathrm{C}\right)$. During filtration, the glossy side of the membrane faced the feed solution, and the membrane can be backwashed by placing the reverse side of the membrane upwards. Nitrogen gas was used to drive feed solution through the membrane, and a constant pressure of $100 \mathrm{kPa}$ was used in this experiment. Permeate was collected into a conical flask placed on an electronic balance connected to a computer, and the weight data were automatically recorded every $5 \mathrm{~s}$.

\subsection{Preparation of HS-Fouled Membranes}

To evaluate the cleaning efficacy of $\mathrm{H}_{2} \mathrm{O}_{2}$ and $\mathrm{NaClO}$ at various $\mathrm{pH}, \mathrm{PES}$ membranes fouled by HS to a similar extent were prepared by filtering HS solution using the membrane and filtration set-up described in Section 2.1. Humic acid obtained from Sigma-Aldrich Chemical Co. (St. Louis, MO, USA) was used as the representative HS. To speed up membrane fouling, a relatively high concentration of HS (i.e., $50 \mathrm{mg} / \mathrm{L}$ ) was used and the corresponding dissolved organic carbon (DOC) concentration was $20.5 \pm 0.6 \mathrm{mg} / \mathrm{L}$. Meanwhile, $1 \mathrm{mmol} / \mathrm{L} \mathrm{CaCl}_{2}, 1 \mathrm{mmol} / \mathrm{L} \mathrm{NaHCO}_{3}$, and $6 \mathrm{mmol} / \mathrm{L} \mathrm{NaCl}$ were added to simulate the solution chemistry in natural water. To focus on physically irreversible fouling, the membrane was backwashed with $50 \mathrm{~mL}$ ultrapure water after filtering $350 \mathrm{~mL}$ HS solution. Based on preliminary experiments (data not shown), two cycles of filtration-backwash were required to obtain a HS-fouled membrane with flux decreasing to $10-15 \%$ of the initial value. The flux of new membrane and fouled membrane was denoted as $\mathrm{J}_{0}$ and $\mathrm{J}_{\mathrm{f}}$, respectively.

\subsection{Cleaning Process and Cleaning Efficacy Evaluation}

All chemicals and reagents used in this study were in analytical grade. Commercially available $\mathrm{NaClO}\left(\sim 10 \%\right.$ in weight) and $\mathrm{H}_{2} \mathrm{O}_{2}(\sim 30 \%$ in weight $)$ were purchased from Tianli Chemical Reagent Co. (Tianjin, China) and Kermel Chemical Reagent Co. (Tianjin, China), respectively. Concentrations of $\mathrm{NaClO}$ and $\mathrm{H}_{2} \mathrm{O}_{2}$ solution were determined by iodometric titration method and permanganate titration method, respectively, and therefore the reported concentrations were sum of all active species in the solutions. $\mathrm{NaClO}$ and $\mathrm{H}_{2} \mathrm{O}_{2}$ cleaning solutions were both diluted to $500 \mathrm{mg} / \mathrm{L}$ using ultrapure water and their $\mathrm{pH}$ were adjusted to 3, 5, 7, 9, and 11 with $\mathrm{HCl}$ or $\mathrm{NaOH}$. $\mathrm{HCl}$ and $\mathrm{NaOH}$ were both obtained from Kermel Chemical Reagent Co. (Tianjin, China). Meanwhile, pure water at the $\mathrm{pH}$ of 3, 5, 7,9 , and 11 was also used as control cleaning solution.

HS-fouled membranes were taken out of the filtration cell and immersed in glassware containing $50 \mathrm{~mL}$ corresponding cleaning solutions. After $6 \mathrm{~h}$ of static soaking, the membranes were rinsed with pure water to remove cleaning agents, and their pure water flux was determined and denoted as $\mathrm{J}_{\mathrm{c}}$. Each cleaning test was conducted in triplicate.

Therefore, the cleaning efficacy of different cleaning solutions can be quantified based on flux recovery ratio (Equation (1)).

$$
\text { Cleaning efficacy }(\%)=\frac{\mathrm{J}_{\mathrm{c}}-\mathrm{J}_{\mathrm{f}}}{\mathrm{J}_{0}-\mathrm{J}_{\mathrm{f}}} \times 100 \%
$$

\subsection{Reaction of HS with Cleaning Agents}

To elucidate cleaning mechanisms of $\mathrm{NaClO}$ and $\mathrm{H}_{2} \mathrm{O}_{2}$ towards $\mathrm{HS}$ fouling, effects of reaction with cleaning agents on fouling potential and properties of HS were examined. HS solutions $(100 \mathrm{mg} / \mathrm{L})$ at certain $\mathrm{pH}$ were dosed with predetermined $\mathrm{NaClO}$ or $\mathrm{H}_{2} \mathrm{O}_{2}$ to obtain an oxidant/DOC ratio of 13:1. Only the $\mathrm{pH}$ of 9 and 11 were investigated because $\mathrm{H}_{2} \mathrm{O}_{2}$ exhibited significant different cleaning efficacy under these two $\mathrm{pH}$, while $\mathrm{NaClO}$ cleaning was commonly conducted under alkaline conditions. After $6 \mathrm{~h}$ of reaction, HS solutions were taken out to perform filtration test and determination of 
UV-Vis absorbance spectra, zeta potential and MW distribution. Meanwhile, HS solutions at the same concentration and $\mathrm{pH}$ were denoted as raw HS solutions.

\subsection{Characterization of Fouling Potential and Properties of HS before and after Reacting with Cleaning Agents}

Fouling potential of raw and cleaning agent-treated HS was evaluated by single-cycle filtration test with the membrane and filtration cell described in Section 2.1. Raw and cleaning agent-treated HS solutions were diluted by 10 times before filtration test, and the initial volume of feed solution was $350 \mathrm{~mL}$. When the permeate volume reached $300 \mathrm{~mL}$, the concentrate with a volume of $50 \mathrm{~mL}$ was discarded, and the membrane was backwashed with $50 \mathrm{~mL}$ pure water. Therefore, the final volume reduction ratio was 7 , and the cumulative volume of permeate per unit membrane surface area $\left(V_{s}\right)$ was $0.067 \mathrm{~m}^{3} / \mathrm{m}^{2}$. Unified membrane fouling index (UMFI) can be used to assess membrane fouling quantitatively [29]. Based on the permeate flux of new membrane $\left(\mathrm{J}_{0}\right)$, the final flux at the end of filtration $\left(\mathrm{J}_{1}\right)$ and the flux after backwash $\left(\mathrm{J}_{2}\right)$, total fouling index, (TFI) and hydraulically irreversible fouling index (HIFI) can be calculated according to Equations (2) and (3), respectively. All filtration tests were conducted in triplicate.

$$
\begin{gathered}
\operatorname{TFI}\left(\mathrm{m}^{-1}\right)=\frac{\mathrm{J}_{0} / \mathrm{J}_{1}-1}{\mathrm{~V}_{\mathrm{s}}} \\
\operatorname{HIFI}\left(\mathrm{m}^{-1}\right)=\frac{\mathrm{J}_{0} / \mathrm{J}_{2}-1}{\mathrm{~V}_{\mathrm{s}}}
\end{gathered}
$$

UV-Vis absorbance spectra of HS solution were measured using U-3900 UV/vis spectrophotometer (Hitachi Ltd, Tokyo, Japan). Differential log transformed absorbance spectra (DLnA) and the spectral parameter (DSlope $325-375$ ) were calculated according to literature and were used as indication of HS properties [30].

Zeta potential of HS was determined by using Nano S90 (Malvern Panalytical Ltd, Malvern, UK). DOC was measured by a total organic carbon analyzer (multi N/C2100, Analytik Jena AG, Jena, Germany). All measurements were done in triplicate.

Molecular weight (MW) distributions of raw and cleaning agent-treated HS were determined using UF separation method in parallel mode. Regenerated cellulose membranes with MWCO of 100, 30, 10 kDa (Amicon YM 100, YM 30, YM 10, Millipore, Burlington, MA, USA) were used. All MW distribution tests were conducted in duplicate, and the detailed procedure of the test can be found in previous literature [31].

\section{Results and Discussion}

\subsection{Efficacy of $\mathrm{H}_{2} \mathrm{O}_{2}$ and $\mathrm{NaClO}$ Cleaning under Various $\mathrm{pH}$}

For both $\mathrm{H}_{2} \mathrm{O}_{2}$ and $\mathrm{NaClO}$ solutions, there is an equilibrium between two or more species depending on solution $\mathrm{pH}$ and temperature. $\mathrm{H}_{2} \mathrm{O}_{2}$ is a weak acid that dissociates in aqueous solution according to Equation (4) [32], while three chlorine species, i.e., $\mathrm{Cl}_{2}, \mathrm{HOCl}$, and $\mathrm{ClO}^{-}$, coexist in $\mathrm{NaClO}$ solution (Equations (5) and (6)) [33]. For $500 \mathrm{mg} / \mathrm{L} \mathrm{H}_{2} \mathrm{O}_{2}$ and $\mathrm{NaClO}$ solution, the distribution of main species as a function of $\mathrm{pH}$ at $25^{\circ} \mathrm{C}$ is shown in Figure $1 \mathrm{a}, \mathrm{b}$, respectively.

$$
\begin{gathered}
\mathrm{H}_{2} \mathrm{O}_{2} \rightleftharpoons \mathrm{HO}_{2}{ }^{-}+\mathrm{H}^{+} \quad \mathrm{k}_{1}=2.2 \times 10^{-12}\left(\mathrm{~T}=25^{\circ} \mathrm{C}\right) \\
\mathrm{Cl}_{2}+\mathrm{H}_{2} \mathrm{O} \rightleftharpoons \mathrm{HOCl}+\mathrm{Cl}^{-}+\mathrm{H}^{+} \quad \mathrm{k}_{2}=5.1 \times 10^{-4}\left(\mathrm{~T}=25^{\circ} \mathrm{C}\right) \\
\mathrm{HOCl} \rightleftharpoons \mathrm{ClO}^{-}+\mathrm{H}^{+} \quad \mathrm{k}_{3}=2.9 \times 10^{-8}\left(\mathrm{~T}=25^{\circ} \mathrm{C}\right)
\end{gathered}
$$



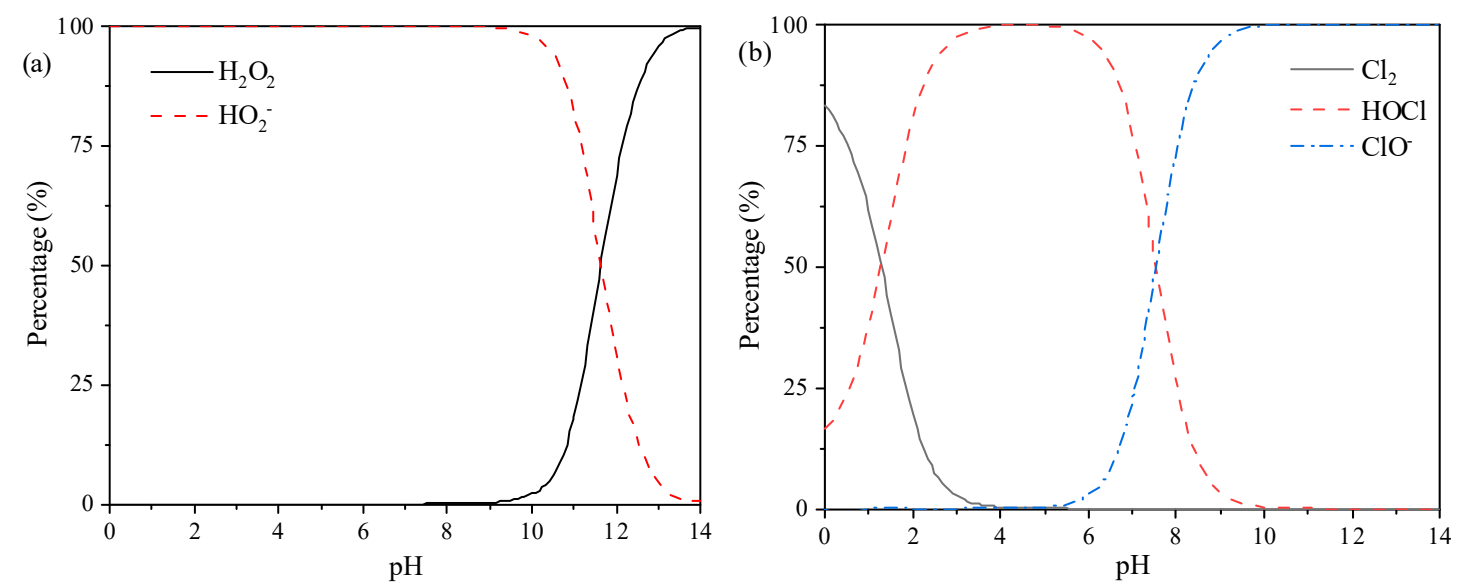

Figure 1. Distribution of main species in $\mathrm{H}_{2} \mathrm{O}_{2}(\mathbf{a})$ and $\mathrm{NaClO}(\mathbf{b})$ solutions as a function of $\mathrm{pH}$ at $25^{\circ} \mathrm{C}$ and for $\mathrm{C}\left(\mathrm{H}_{2} \mathrm{O}_{2}\right)_{\mathrm{T}}=\mathrm{C}(\mathrm{NaClO})_{\mathrm{T}}=500 \mathrm{mg} / \mathrm{L}$.

As for $\mathrm{H}_{2} \mathrm{O}_{2}$ solution, almost no dissociation of $\mathrm{H}_{2} \mathrm{O}_{2}$ occurs at $\mathrm{pH}<9$, while the percentage of $\mathrm{HO}_{2}{ }^{-}$increases rapidly when the solution $\mathrm{pH}$ exceeds 10 . At the $\mathrm{pH}$ of 11 , about $18 \%$ of $\mathrm{H}_{2} \mathrm{O}_{2}$ is dissociated to the form of $\mathrm{HO}_{2}{ }^{-}$. Based on the standard electrode potential $\left(\mathrm{E}_{0}\right)$, oxidation capacity of $\mathrm{H}_{2} \mathrm{O}_{2} / \mathrm{H}_{2} \mathrm{O}\left(E_{0}=1.78 \mathrm{~V}\right)$ is stronger than $\mathrm{HO}_{2}{ }^{-} / \mathrm{OH}^{-}\left(E_{0}=0.88 \mathrm{~V}\right)$. With respect to $\mathrm{NaClO}$ solution, $\mathrm{Cl}_{2}$ and $\mathrm{HOCl}$ are the dominant species at $\mathrm{pH}<4$, while $\mathrm{HOCl}$ and $\mathrm{ClO}^{-}$coexist at $\mathrm{pH} 5-10$. At $\mathrm{pH}>10$, almost all chlorine exists in the form of $\mathrm{ClO}^{-}$. The oxidation capacity of chlorine species is in the range of $\mathrm{HClO} / \mathrm{Cl}^{-}\left(E_{0}=1.49 \mathrm{~V}\right)>\mathrm{Cl}_{2}(\mathrm{aq}) / \mathrm{Cl}^{-}\left(E_{0}=1.40 \mathrm{~V}\right)>\mathrm{ClO}^{-} / \mathrm{Cl}^{-}\left(E_{0}=0.89 \mathrm{~V}\right)$. As a result, it can be speculated that the oxidation capacity of both $\mathrm{H}_{2} \mathrm{O}_{2}$ and $\mathrm{NaClO}$ solutions would decrease with the increase of $\mathrm{pH}$.

Effects of $\mathrm{pH}$ on cleaning efficacy of $\mathrm{H}_{2} \mathrm{O}_{2}$ and $\mathrm{NaClO}$ for HS-fouled membrane are shown in Figure 2. For the control group, alkaline cleaning at $\mathrm{pH} 11$ achieved the highest cleaning efficacy $(72.2 \%)$, whereas acid cleaning was just slightly better than cleaning by pure water. The major mechanism of alkaline cleaning for organic fouling was solubilization and hydrolysis of organic foulants, which promotes swelling of the fouling layer and detachment from membrane surface $[24,34,35]$. As for $\mathrm{H}_{2} \mathrm{O}_{2}$, the cleaning efficacy at $\mathrm{pH} 3$ was $22.6 \%$, and it decreased slightly to $13.9-16.3 \%$ at $\mathrm{pH} 5-9$. The results seemed to be consistent with the decrease of oxidation capacity, but the cleaning efficacy at $\mathrm{pH}$ 11 increased remarkably to $91.4 \%$. Even taking into account the cleaning efficacy of alkaline cleaning, the contribution of $\mathrm{H}_{2} \mathrm{O}_{2}$ was higher at $\mathrm{pH}$ 11. Strugholtz et al. [24] also reported the increase of $\mathrm{H}_{2} \mathrm{O}_{2}$ cleaning efficacy due to combination with $\mathrm{NaOH}$, but the reason was not explored. With respect to $\mathrm{NaClO}$, the cleaning efficacy improved with the increase of $\mathrm{pH}$ from 3 to 9 , and the cleaning efficacy was $99.4 \%$ and $95.2 \%$ at $\mathrm{pH} 9$ and 11 , respectively. Wang et al. [36] observed similar results and ascribed the better performance at higher $\mathrm{pH}$ to the uneven and fast diffusion of $\mathrm{ClO}^{-}$, but the variation of properties of organic foulants during chemical cleaning was not examined. As shown in Figure S1 in the Supplementary Materials, PES membrane was stable after exposure to these cleaning agents at $\mathrm{pH}$ 11 , suggesting the recovery of permeability was not due to membrane damage. In short, for HS-fouled UF membrane, $\mathrm{H}_{2} \mathrm{O}_{2}$ cleaning at $\mathrm{pH} 11$ might be a feasible alternative for $\mathrm{NaClO}$ cleaning considering cleaning efficacy and reduction of chlorinated by-products. 


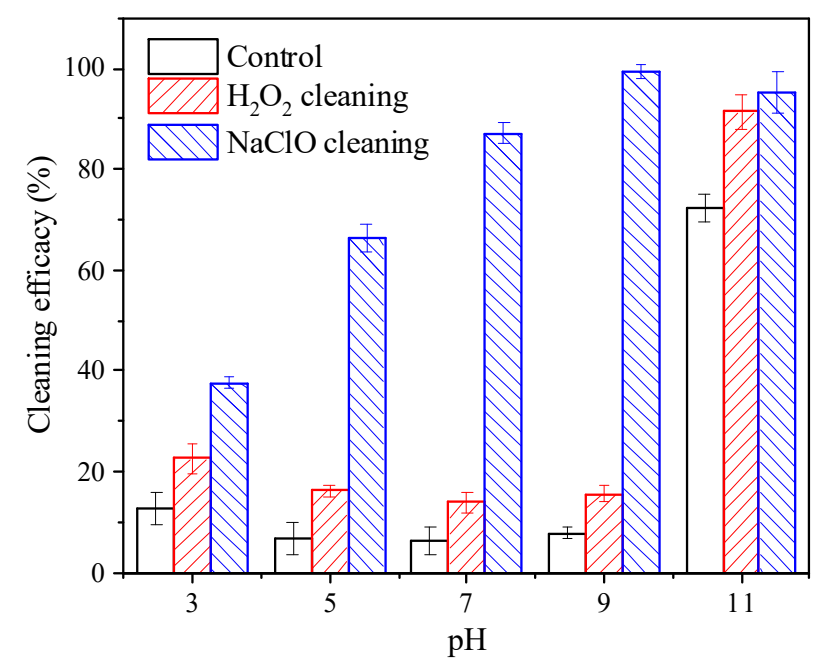

Figure 2. Effects of $\mathrm{pH}$ on cleaning efficacy of $\mathrm{H}_{2} \mathrm{O}_{2}$ and $\mathrm{NaClO}$ for ultrafiltration (UF) membranes fouled by humic substances (HS). $\mathrm{C}\left(\mathrm{H}_{2} \mathrm{O}_{2}\right)_{\mathrm{T}}=\mathrm{C}(\mathrm{NaClO})_{\mathrm{T}}=500 \mathrm{mg} / \mathrm{L}$, with pure water as control, and $\mathrm{pH}$ was adjusted by adding $\mathrm{HCl}$ or $\mathrm{NaOH}$; cleaning time $6 \mathrm{~h}$.

\subsection{Fouling Potential of $\mathrm{HS}$ before and after Reacting with $\mathrm{H}_{2} \mathrm{O}_{2}$ and $\mathrm{NaClO}$}

To verify the effectiveness of $\mathrm{H}_{2} \mathrm{O}_{2}$ in membrane cleaning, fouling potential of $\mathrm{HS}$ before and after reacting with $\mathrm{H}_{2} \mathrm{O}_{2}$ and $\mathrm{NaClO}$ at $\mathrm{pH} 9$ and 11 was investigated, and the results are shown in Figure 3. It can be seen that raw HS solutions at $\mathrm{pH} 9$ and 11 resulted in similar flux decline pattern, and permeate flux at the end of filtration cycle decreased to about $51 \%$ of the initial flux. The trend was not affected by $\mathrm{H}_{2} \mathrm{O}_{2}$ treatment at $\mathrm{pH} 9$, whereas flux decline was significantly alleviated due to $\mathrm{H}_{2} \mathrm{O}_{2}$ treatment at $\mathrm{pH} 11$, with the ending flux accounting for $65 \%$ of the initial one. Flux decline was substantially abated by $\mathrm{NaClO}$ treatment at both $\mathrm{pH} 9$ and 11 , and the final flux was $77 \%$ and $68 \%$ of the initial flux, respectively. As shown in Figure S2 in the Supplementary Materials, rejection of HS was significantly reduced due to reacting with $\mathrm{H}_{2} \mathrm{O}_{2}$ at $\mathrm{pH} 11$ and with $\mathrm{NaClO}$ at $\mathrm{pH} 9$ and 11, which was consistent with the flux decline trends. Hydraulically irreversible fouling was quantified by HIFI and the results are presented in Figure 3b. At pH 9, much lower irreversible fouling occurred after $\mathrm{NaClO}$ treatment, with $\mathrm{H}_{2} \mathrm{O}_{2}$ and $\mathrm{NaClO}$ treatment reducing $\mathrm{HIFI}$ by $24.0 \%$ and $70.5 \%$, respectively. For $\mathrm{pH} 11, \mathrm{H}_{2} \mathrm{O}_{2}$ and $\mathrm{NaClO}$ treatment resulted in $48.4 \%$ and $56.4 \%$ decrease of HIFI, respectively.
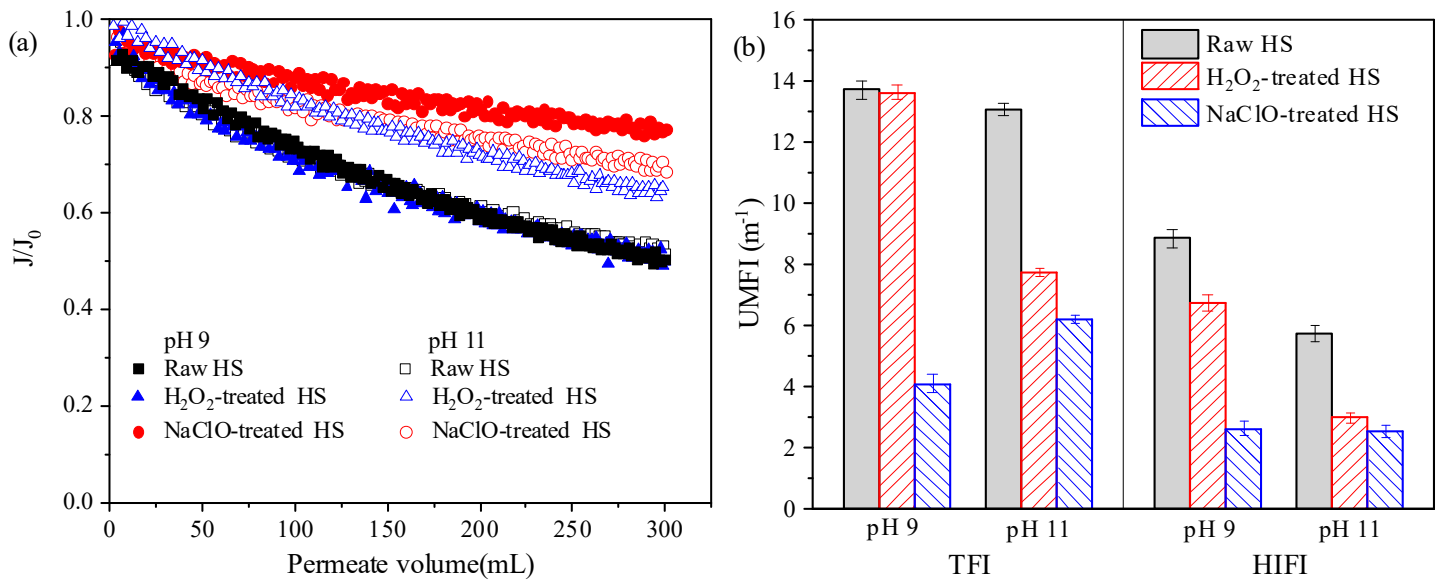

Figure 3. Fouling potential of $\mathrm{HS}$ before and after reacting with $\mathrm{H}_{2} \mathrm{O}_{2}$ and $\mathrm{NaClO}$ : (a) Flux decline, (b) unified membrane fouling index (UMFI). The ratio of oxidant to dissolved organic carbon (DOC): 13:1; reaction time: $6 \mathrm{~h}$. (TFI: total fouling index, HIFI: hydraulically irreversible fouling index). 
In short, $\mathrm{H}_{2} \mathrm{O}_{2}$ treatment at $\mathrm{pH} 9$ exerted minor influence on fouling potential of $\mathrm{HS}$, whereas $\mathrm{H}_{2} \mathrm{O}_{2}$ treatment at $\mathrm{pH} 11$ remarkably decreased both total and irreversible fouling caused by HS. As for $\mathrm{NaClO}$ treatment, fouling potential of $\mathrm{HS}$ was effectively reduced at both $\mathrm{pH} 9$ and 11 , and the decrease of total fouling was a little more pronounced at $\mathrm{pH}$ 9. These results were consistent with the cleaning efficacy of $\mathrm{H}_{2} \mathrm{O}_{2}$ and $\mathrm{NaClO}$, as illustrated in Figure 2. At $\mathrm{pH} 11$, both $\mathrm{H}_{2} \mathrm{O}_{2}$ and $\mathrm{NaClO}$ treatment significantly decreased fouling potential of HS, indicating that HS properties were obviously changed by these two cleaning agents. Therefore, the significant increase of $\mathrm{H}_{2} \mathrm{O}_{2}$ cleaning efficacy with the increase of $\mathrm{pH}$ from 9 to 11 should not be solely attributed to alkali solubilization, and variation of HS properties played an important role.

\subsection{Alteration of $\mathrm{HS}$ Properties Due to Reacting with $\mathrm{H}_{2} \mathrm{O}_{2}$ and $\mathrm{NaClO}$}

To elucidate cleaning mechanisms of $\mathrm{H}_{2} \mathrm{O}_{2}$ and $\mathrm{NaClO}$ at $\mathrm{pH} 9$ and 11 , several properties of $\mathrm{HS}$ before and after reacting with $\mathrm{H}_{2} \mathrm{O}_{2}$ and $\mathrm{NaClO}$ were examined. It should be noted that the decrease of DOC caused by reacting with $\mathrm{H}_{2} \mathrm{O}_{2}$ and $\mathrm{NaClO}$ was less than $10 \%$, suggesting minimal mineralization of HS during reactions.

Figure 4 presents zeta potential of $\mathrm{HS}$ before and after reacting with $\mathrm{H}_{2} \mathrm{O}_{2}$ and $\mathrm{NaClO}$. It can be seen that $\mathrm{HS}$ was negatively charged, and zeta potential of raw $\mathrm{HS}$ at $\mathrm{pH} 9$ and 11 was -30.8 and $-34.1 \mathrm{mV}$, respectively. At $\mathrm{pH} 9$, zeta potential of $\mathrm{HS}$ was only slightly decreased by $\mathrm{H}_{2} \mathrm{O}_{2}$ treatment, whereas it was obviously decreased to $-43.7 \mathrm{mV}$ by $\mathrm{NaClO}$ treatment. For $\mathrm{pH} 11$, zeta potential of $\mathrm{HS}$ was decreased to -41.3 and $-42.4 \mathrm{mV}$ due to $\mathrm{H}_{2} \mathrm{O}_{2}$ and $\mathrm{NaClO}$ treatment, respectively. Because the membrane used in this study was negatively charged $(-15.9 \pm 0.3 \mathrm{mV}$ in $1 \mathrm{mM} \mathrm{KCl}$ solution at $\mathrm{pH} 7$ ), the decrease of zeta potential, i.e., the increase of negative charge, would enhance electrostatic repulsion and weaken the adhesion force between HS and the membrane [2]. Therefore, the higher cleaning efficacy of $\mathrm{H}_{2} \mathrm{O}_{2}$ at $\mathrm{pH} 11$ can be partly attributed to the more significant decrease of zeta potential caused by $\mathrm{H}_{2} \mathrm{O}_{2}$ treatment at $\mathrm{pH} 11$.

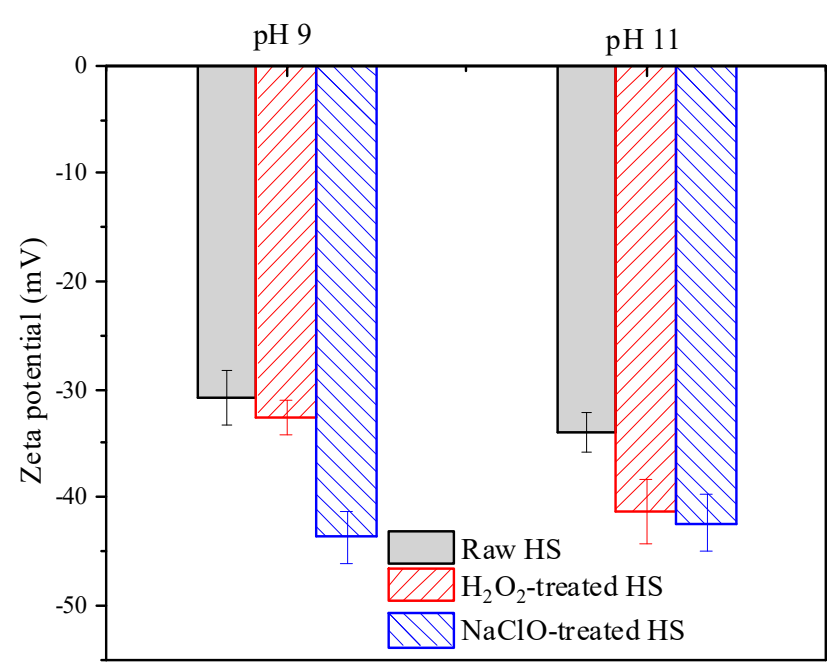

Figure 4. Zeta potential of $\mathrm{HS}$ before and after reacting with $\mathrm{H}_{2} \mathrm{O}_{2}$ and $\mathrm{NaClO}$. The ratio of oxidant to DOC: $13: 1$; reaction time: $6 \mathrm{~h}$.

MW distributions of $\mathrm{HS}$ before and after reacting with $\mathrm{H}_{2} \mathrm{O}_{2}$ and $\mathrm{NaClO}$ are shown in Figure 5 . At $\mathrm{pH} 9$, the fraction of high-MW ( $>100 \mathrm{kDa}$ ) accounted for $57.3 \%$ of raw HS based on DOC, while the fractions with MW of 10-30 kDa and $<10 \mathrm{kDa}$ made up 19.8\% and $19.3 \%$, respectively. After $\mathrm{H}_{2} \mathrm{O}_{2}$ treatment, the ratio of the high-MW fraction slightly decreased to $48.2 \%$, accompanying with some increase of the 10-30 kDa fraction. In contrast, $\mathrm{NaClO}$ treatment led to substantial decrease of the high-MW fraction, and the percentage of the fraction with MW of $<10 \mathrm{kDa}$ was increased remarkably to $71.2 \%$. At $\mathrm{pH} 11$, raw HS exhibited similar MW distribution with that at $\mathrm{pH} 9$, but the change 
caused by $\mathrm{H}_{2} \mathrm{O}_{2}$ treatment was much more obvious. After $\mathrm{H}_{2} \mathrm{O}_{2}$ treatment, proportion of the high-MW fraction was decreased from $51.5 \%$ to $28.2 \%$, while ratios of the fractions with MW of $10-30 \mathrm{kDa}$ and $<$ $10 \mathrm{kDa}$ were increased to $24.4 \%$ and $42.6 \%$, respectively.
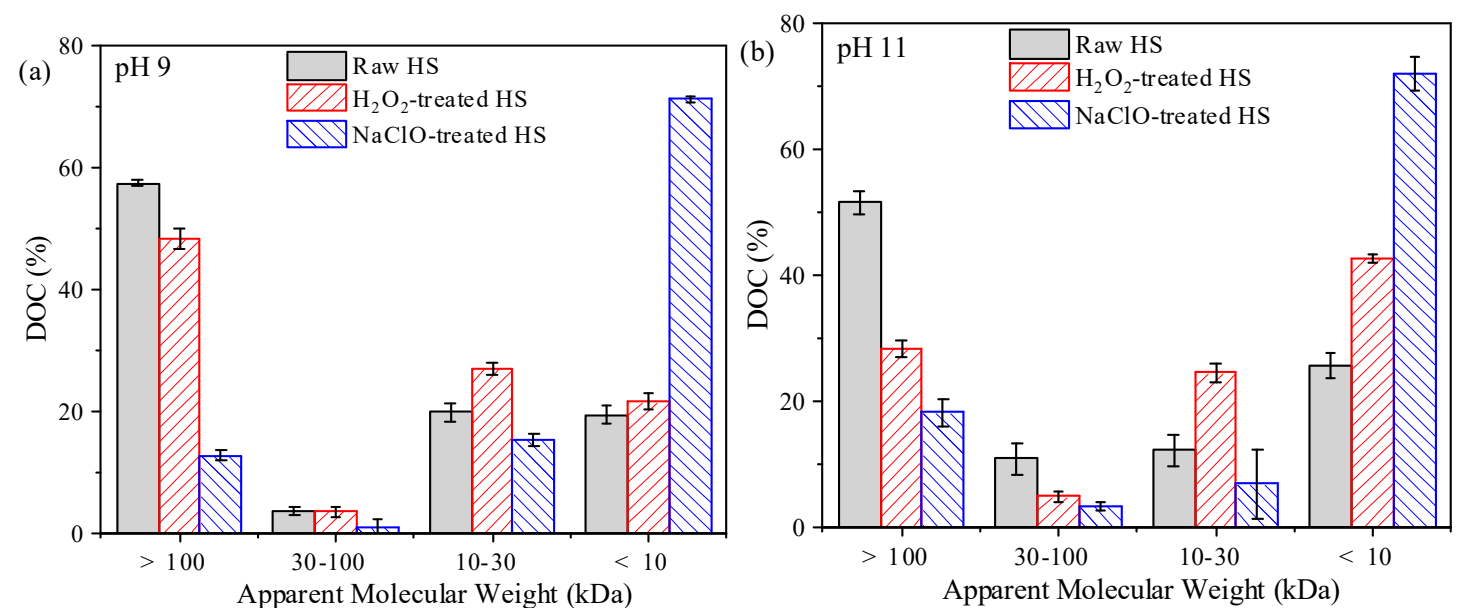

Figure 5. Apparent molecular weight distributions of $\mathrm{HS}$ before and after reacting with $\mathrm{H}_{2} \mathrm{O}_{2}$ and NaClO: (a) $\mathrm{pH}$ 9, (b) $\mathrm{pH}$ 11. The ratio of oxidant to DOC: 13:1; reaction time: $6 \mathrm{~h}$.

UV-Vis spectral parameters can provide abundant information about the composition and structure of HS and have been successfully applied to characterize properties of HS [37], binding of metal ions on it [38,39], as well as its reactions with oxidants [40]. The differential log-transformed absorbance spectra $(D L n A)$ and variation in spectral slope determined in the wavelength range from 325 to $375 \mathrm{~nm}$ (DSlope $325-375$ ) of $\mathrm{HS}$ before and after reacting with $\mathrm{H}_{2} \mathrm{O}_{2}$ and $\mathrm{NaClO}$ are shown in Figure 6. It can be seen that the absorbance spectra of $\mathrm{HS}$ changed greatly after $\mathrm{NaClO}$ treatment, and the change at $\mathrm{pH}$ 9 was more remarkable than that at $\mathrm{pH} 11$. In comparison, variations of the absorbance spectra due to $\mathrm{H}_{2} \mathrm{O}_{2}$ treatment were insignificant. Considering the significant change of zeta potential and MW distribution of HS due to $\mathrm{H}_{2} \mathrm{O}_{2}$ treatment at $\mathrm{pH}$ 11, it seems that UV-Vis spectra was not suitable for the characterization of the reaction between $\mathrm{HS}$ and $\mathrm{H}_{2} \mathrm{O}_{2}$.
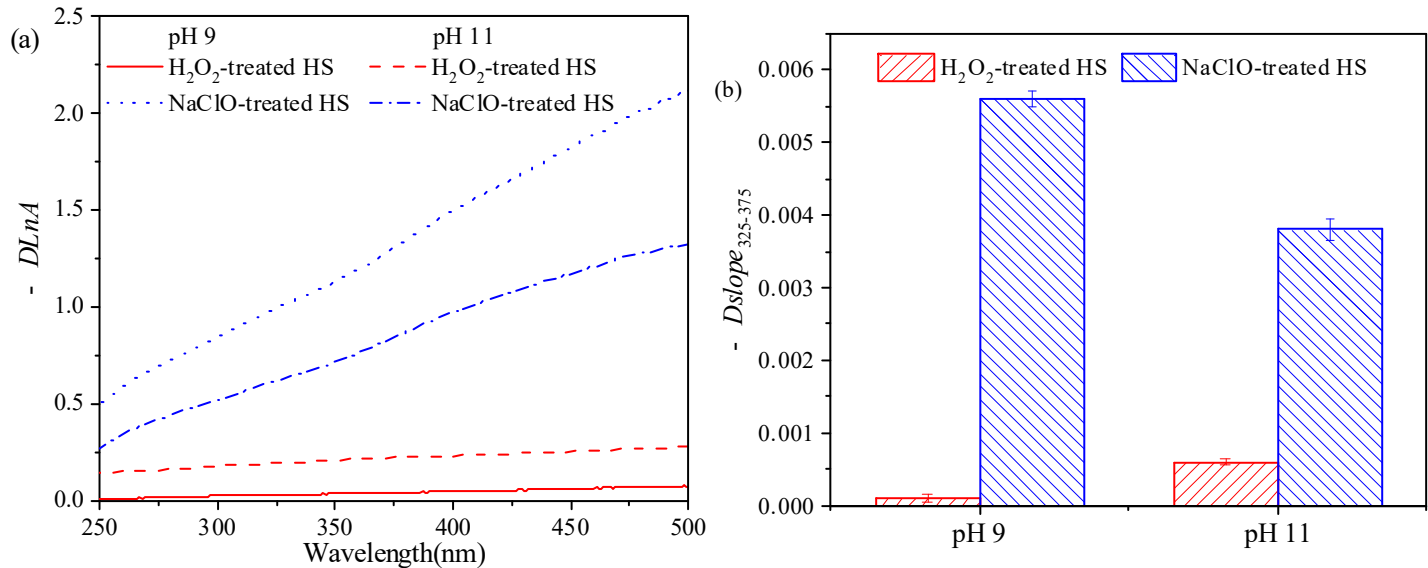

Figure 6. Differential log-transformed absorbance spectra $(-D \operatorname{Ln} A)(\mathbf{a})$ and change in spectral parameter (-DSlope $325-375)(\mathbf{b})$ of $\mathrm{HS}$ before and after reacting with $\mathrm{H}_{2} \mathrm{O}_{2}$ and $\mathrm{NaClO}$. The ratio of oxidant to DOC: 13:1; reaction time: $6 \mathrm{~h}$.

Based on the alteration of zeta potential, MW distribution, and absorbance spectra parameters of HS before and after reacting with two cleaning agents, it can be concluded that $\mathrm{NaClO}$ can effectively oxidize HS at both pH 9 and 11, while HS can only be oxidized by $\mathrm{H}_{2} \mathrm{O}_{2}$ at $\mathrm{pH} 11$. The results were 
consistent with their cleaning efficacy and the corresponding fouling potential. For $\mathrm{NaClO}$, the greater change of $\mathrm{HS}$ properties at $\mathrm{pH} 9$ can be attributed to the higher $E_{0}$ of $\mathrm{HClO}$ species and generation of $\mathrm{OH}$ due to the coexistence of $\mathrm{HClO}$ and $\mathrm{ClO}^{-}$[41]. With respect to $\mathrm{H}_{2} \mathrm{O}_{2}$, the discrepancy of oxidation capacity at $\mathrm{pH} 9$ and 11 cannot be explained by the $E_{0}$ of $\mathrm{H}_{2} \mathrm{O}_{2}(1.78 \mathrm{~V})$ and $\mathrm{HO}_{2}{ }^{-}(0.88 \mathrm{~V})$. The generation of various reactive oxygen species in $\mathrm{H}_{2} \mathrm{O}_{2}$ solution under strong alkaline condition might be responsible for the higher cleaning efficacy and oxidation capacity of $\mathrm{H}_{2} \mathrm{O}_{2}$ towards $\mathrm{HS}$ at pH $11[28,32]$.

\section{Conclusions}

In this study, cleaning efficacy of $\mathrm{H}_{2} \mathrm{O}_{2}$ and $\mathrm{NaClO}$ at a wide $\mathrm{pH}$ range (3-11) for UF membrane fouled by HS was investigated, and properties of $\mathrm{HS}$ before and after reacting with cleaning agents were analyzed. The cleaning efficacy of $\mathrm{H}_{2} \mathrm{O}_{2}$ was lower than that of $\mathrm{NaClO}$ at $\mathrm{pH} 3-9$, while it increased significantly to $91.4 \%$ and was comparable with that of $\mathrm{NaClO}$ at $\mathrm{pH} 11$. The extents of changes in properties and fouling potential of $\mathrm{HS}$ due to reacting with $\mathrm{H}_{2} \mathrm{O}_{2}$ and $\mathrm{NaClO}$ at both $\mathrm{pH}$ 9 and 11 was consistent with the cleaning efficacy. $\mathrm{H}_{2} \mathrm{O}_{2}$ treatment exerted minor influence on HS properties at $\mathrm{pH}$ 9, but it led to significant increase of negative charge, decomposition of high-MW molecules, and reduction of both total and irreversible fouling at $\mathrm{pH} 11$. Considering the cleaning efficacy and control of chlorinated by-products during chemical cleaning, $\mathrm{H}_{2} \mathrm{O}_{2}$ cleaning under strong alkaline condition can be a good alternative for $\mathrm{NaClO}$ cleaning for HS-fouled UF membrane.

Supplementary Materials: The following are available online at http://www.mdpi.com/1660-4601/16/14/2568/s1, Figure S1: SEM images of pristine membrane and membranes exposure to cleaning agents at $\mathrm{pH} 11$ for $6 \mathrm{~h}(\times$ 100,000 magnification): (a) pristine membrane, (b) pure water, (c) $500 \mathrm{mg} / \mathrm{L} \mathrm{H}_{2} \mathrm{O}_{2}$, (d) $500 \mathrm{mg} / \mathrm{L} \mathrm{NaClO;} \mathrm{Figure} \mathrm{S2:}$ Rejection of $\mathrm{HS}$ before and after reacting with $\mathrm{H}_{2} \mathrm{O}_{2}$ and $\mathrm{NaClO}$. The ratio of oxidant to DOC: 13:1; reaction time: $6 \mathrm{~h}$.

Author Contributions: Conceptualization, K.L. and T.H.; Funding acquisition, T.H.; Investigation, K.L., S.L., C.D. and J.L.; Methodology, C.D., J.L., B.Z. and S.Z.; Validation, B.Z. and S.Z.; Writing-original draft, S.L.; Writing-review \& editing, K.L. and T.H.

Funding: This research was jointly supported by National Natural Science Foundation of China (51608427), Key Research and Development Program of Shaanxi province (2019ZDLSF06-01), Innovation and Entrepreneurship Training Program for College students of Shaanxi Province (201809076) and The Youth Innovation Team of Shaanxi Universities Funded by Education Department of Shaanxi Province.

Conflicts of Interest: The authors declare no conflict of interest.

\section{References}

1. Huttinger, A.; Dreibelbis, R.; Roha, K.; Ngabo, F.; Kayigamba, F.; Mfura, L.; Moe, C. Evaluation of Membrane Ultrafiltration and Residual Chlorination as a Decentralized Water Treatment Strategy for Ten Rural Healthcare Facilities in Rwanda. Int. J. Environ. Res. Public Health 2015, 12, 13602-13623. [CrossRef] [PubMed]

2. Li, K.; Wen, G.; Li, S.; Chang, H.; Shao, S.; Huang, T.; Li, G.; Liang, H. Effect of pre-oxidation on low pressure membrane (LPM) for water and wastewater treatment: A review. Chemosphere 2019, 231, 287-300. [CrossRef] [PubMed]

3. Hu, Y.; Wang, X.C.; Ngo, H.H.; Sun, Q.; Yang, Y. Anaerobic dynamic membrane bioreactor (AnDMBR) for wastewater treatment: A review. Bioresour. Technol. 2018, 247, 1107-1118. [CrossRef] [PubMed]

4. Shao, S.; Fu, W.; Li, X.; Shi, D.; Jiang, Y.; Li, J.; Gong, T.; Li, X. Membrane fouling by the aggregations formed from oppositely charged organic foulants. Water Res. 2019, 159, 95-101. [CrossRef] [PubMed]

5. Tian, J.Y.; Ernst, M.; Cui, F.; Jekel, M. Correlations of relevant membrane foulants with UF membrane fouling in different waters. Water Res. 2013, 47, 1218-1228. [CrossRef]

6. Li, K.; Huang, T.; Qu, F.; Du, X.; Ding, A.; Li, G.; Liang, H. Performance of adsorption pretreatment in mitigating humic acid fouling of ultrafiltration membrane under environmentally relevant ionic conditions. Desalination 2016, 377, 91-98. [CrossRef] 
7. Tian, J.; Wu, C.; Yu, H.; Gao, S.; Li, G.; Cui, F.; Qu, F. Applying ultraviolet/persulfate (UV/PS) pre-oxidation for controlling ultrafiltration membrane fouling by natural organic matter (NOM) in surface water. Water Res. 2018, 132, 190-199. [CrossRef]

8. Anari, Z.; Sengupta, A.; Wickramasinghe, S.R. Surface Oxidation of Ethylenechlorotrifluoroethylene (ECTFE) Membrane for the Treatment of Real Produced Water by Membrane Distillation. Int. J. Environ. Res. Public Health 2018, 15. [CrossRef]

9. Liu, F.; Hashim, N.A.; Liu, Y.; Abed, M.R.M.; Li, K. Progress in the production and modification of PVDF membranes. J. Membr. Sci. 2011, 375, 1-27. [CrossRef]

10. Field, R.W.; Wu, D.; Howell, J.A.; Gupta, B.B. Critical flux concept for microfiltration fouling. J. Membr. Sci. 1995, 100, 259-272. [CrossRef]

11. Du, X.; Qu, F.-S.; Liang, H.; Li, K.; Bai, L.-M.; Li, G.-B. Control of submerged hollow fiber membrane fouling caused by fine particles in photocatalytic membrane reactors using bubbly flow: Shear stress and particle forces analysis. Sep. Purif. Technol. 2017, 172, 130-139. [CrossRef]

12. Wang, Z.; Ma, J.; Tang, C.Y.; Kimura, K.; Wang, Q.; Han, X. Membrane cleaning in membrane bioreactors: A review. J. Membr. Sci. 2014, 468, 276-307. [CrossRef]

13. Porcelli, N.; Judd, S. Chemical cleaning of potable water membranes: A review. Sep. Purif. Technol. 2010, 71, 137-143. [CrossRef]

14. Rudolph, G.; Schagerlof, H.; Morkeberg Krogh, K.B.; Jonsson, A.S.; Lipnizki, F. Investigations of Alkaline and Enzymatic Membrane Cleaning of Ultrafiltration Membranes Fouled by Thermomechanical Pulping Process Water. Membranes (Basel) 2018, 8. [CrossRef]

15. Regula, C.; Carretier, E.; Wyart, Y.; Gesan-Guiziou, G.; Vincent, A.; Boudot, D.; Moulin, P. Chemical cleaning/disinfection and ageing of organic UF membranes: A review. Water Res. 2014, 56, 325-365. [CrossRef]

16. Zhou, Z.; He, X.; Zhou, M.; Meng, F. Chemically induced alterations in the characteristics of fouling-causing bio-macromolecules-Implications for the chemical cleaning of fouled membranes. Water Res. 2016. [CrossRef]

17. Zhai, S.; Zhang, W.; Li, T.; Zhang, W.; Lv, L.; Pan, B. Sodium hypochlorite assisted membrane cleaning: Alterations in the characteristics of organic foulants and membrane permeability. Chemosphere 2018, 211, 139-148. [CrossRef]

18. Xie, P.; de Lannoy, C.-F.; Ma, J.; Wiesner, M.R. Chlorination of polyvinyl pyrrolidone-polysulfone membranes: Organic compound release, byproduct formation, and changes in membrane properties. J. Membr. Sci. 2015, 489, 28-35. [CrossRef]

19. Cai, W.; Liu, J.; Zhang, X.; Ng, W.J.; Liu, Y. Generation of dissolved organic matter and byproducts from activated sludge during contact with sodium hypochlorite and its implications to on-line chemical cleaning in MBR. Water Res. 2016, 104, 44-52. [CrossRef]

20. Cai, W.; Liu, J.; Zhu, X.; Zhang, X.; Liu, Y. Fate of dissolved organic matter and byproducts generated from on-line chemical cleaning with sodium hypochlorite in MBR. Chem. Eng. J. 2017, 323, 233-242. [CrossRef]

21. Wang, Z.; Ding, J.; Xie, P.; Chen, Y.; Wan, Y.; Wang, S. Formation of halogenated by-products during chemical cleaning of humic acid-fouled UF membrane by sodium hypochlorite solution. Chem. Eng. J. 2018, 332, 76-84. [CrossRef]

22. Zhang, X.; Liu, Y. Halogenated organics generated during online chemical cleaning of MBR: An emerging threat to water supply and public health. Sci. Total Environ. 2019, 656, 547-549. [CrossRef]

23. Li, X.; Li, J.; Fu, X.; Wickramasinghe, R.; Chen, J. Chemical cleaning of PS ultrafilters fouled by the fermentation broth of glutamic acid. Sep. Purif. Technol. 2005, 42, 181-187. [CrossRef]

24. Strugholtz, S.; Sundaramoorthy, K.; Panglisch, S.; Lerch, A.; Brügger, A.; Gimbel, R. Evaluation of the performance of different chemicals for cleaning capillary membranes. Desalination 2005, 179, 191-202. [CrossRef]

25. Wang, X.; Hu, T.; Wang, Z.; Li, X.; Ren, Y. Permeability recovery of fouled forward osmosis membranes by chemical cleaning during a long-term operation of anaerobic osmotic membrane bioreactors treating low-strength wastewater. Water Res. 2017, 123, 505-512. [CrossRef]

26. Kuzmenko, D.; Arkhangelsky, E.; Belfer, S.; Freger, V.; Gitis, V. Chemical cleaning of UF membranes fouled by BSA. Desalination 2005, 179, 323-333. [CrossRef] 
27. Maartens, A.; Jacobs, E.P.; Swart, P. UF of pulp and paper effluent: Membrane fouling-prevention and cleaning. J. Membr. Sci. 2002, 209, 81-92. [CrossRef]

28. Wang, D.; Zou, J.; Cai, H.; Huang, Y.; Li, F.; Cheng, Q. Effective degradation of Orange G and Rhodamine B by alkali-activated hydrogen peroxide: Roles of $\mathrm{HO}_{2}{ }^{-}$and $\mathrm{O}_{2}{ }^{--}$. Environ. Sci. Pollut. Res. 2019, 26, 1445-1454. [CrossRef]

29. Huang, H.; Young, T.A.; Jacangelo, J.G. Unified Membrane Fouling Index for Low Pressure Membrane Filtration of Natural Waters: Principles and Methodology. Environ. Sci. Technol. 2008, 42, 714-720. [CrossRef]

30. Zhou, M.; Zhou, Z.; Meng, F. Using UV-vis spectral parameters to characterize the cleaning efficacy and mechanism of sodium hypochlorite $(\mathrm{NaOCl})$ on fouled membranes. J. Membr. Sci. 2017, 527, 18-25. [CrossRef]

31. Li, K.; Qu, F.; Liang, H.; Shao, S.; Han, Z.-S.; Chang, H.; Du, X.; Li, G. Performance of mesoporous adsorbent resin and powdered activated carbon in mitigating ultrafiltration membrane fouling caused by algal extracellular organic matter. Desalination 2014, 336, 129-137. [CrossRef]

32. Li, Y.; Li, L.; Chen, Z.X.; Zhang, J.; Gong, L.; Wang, Y.X.; Zhao, H.Q.; Mu, Y. Carbonate-activated hydrogen peroxide oxidation process for azo dye decolorization: Process, kinetics, and mechanisms. Chemosphere 2018, 192, 372-378. [CrossRef]

33. Deborde, M.; von Gunten, U. Reactions of chlorine with inorganic and organic compounds during water treatment-Kinetics and mechanisms: A critical review. Water Res. 2008, 42, 13-51. [CrossRef]

34. Zondervan, E.; Roffel, B. Evaluation of different cleaning agents used for cleaning ultra filtration membranes fouled by surface water. J. Membr. Sci. 2007, 304, 40-49. [CrossRef]

35. Yamamura, H.; Kimura, K.; Watanabe, Y. Mechanism Involved in the Evolution of Physically Irreversible Fouling in Microfiltration and Ultrafiltration Membranes Used for Drinking Water Treatment. Environ. Sci. Technol. 2007, 41, 6789-6794. [CrossRef]

36. Wang, X.; Ma, J.; Wang, Z.; Chen, H.; Liu, M.; Wu, Z. Reinvestigation of membrane cleaning mechanisms using NaOCl: Role of reagent diffusion. J. Membr. Sci. 2018, 550, 278-285. [CrossRef]

37. Roccaro, P.; Yan, M.; Korshin, G.V. Use of log-transformed absorbance spectra for online monitoring of the reactivity of natural organic matter. Water Res. 2015, 84, 136-143. [CrossRef]

38. Gao, Y.; Yan, M.; Korshin, G. Effects of calcium on the chromophores of dissolved organic matter and their interactions with copper. Water Res. 2015, 81, 47-53. [CrossRef]

39. Yan, M.; Wang, D.; Korshin, G.V.; Benedetti, M.F. Quantifying metal ions binding onto dissolved organic matter using log-transformed absorbance spectra. Water Res. 2013, 47, 2603-2611. [CrossRef]

40. Huang, S.; Gan, W.; Yan, M.; Zhang, X.; Zhong, Y.; Yang, X. Differential UV-vis absorbance can characterize the reaction of organic matter with $\mathrm{ClO}_{2}$. Water Res. 2018, 139, 442-449. [CrossRef]

41. Pellegrin, B.; Prulho, R.; Rivaton, A.; Thérias, S.; Gardette, J.-L.; Gaudichet-Maurin, E.; Causserand, C. Multi-scale analysis of hypochlorite induced PES/PVP ultrafiltration membranes degradation. J. Membr. Sci. 2013, 447, 287-296. [CrossRef]

(C) 2019 by the authors. Licensee MDPI, Basel, Switzerland. This article is an open access article distributed under the terms and conditions of the Creative Commons Attribution (CC BY) license (http://creativecommons.org/licenses/by/4.0/). 